\section{Report of a Case of IgE-Mediated Anaphylaxis to Fenugreek}

Aurich $\mathrm{S}^{1,2 *}$, Spiric $\mathrm{J}^{3 *}$, Engin $\mathrm{A}^{3}$, Simon $\mathrm{JC}^{1,2}$, Mahler $\mathrm{V}^{3}$, Treudler $\mathrm{R}^{1,2}$

${ }^{1}$ Department of Dermatology, Venereology and Allergology, Universität Leipzig, Leipzig, Germany

${ }^{2}$ LICA - Leipziger Interdisziplinäres Centrum für Allergologie, Leipzig, Germany

${ }^{3}$ Division of Allergology, Paul-Ehrlich-Institut, Langen, Germany *Both authors contributed equally to the manuscript.

J Investig Allergol Clin Immunol 2019; Vol. 29(1): 56-58 doi: $10.18176 /$ jiaci.0328

Key words: Fenugreek seeds. Food allergy. Anaphylaxis. Oral food challenge. 2-dimensional electrophoresis.

Palabras clave: Semillas de fenogreco. Alergia alimentaria. Anafilaxia. Provocación alimentaria oral. Electroforesis bidimensional.

Fenugreek (Trigonella foenum-graecum) is an annual plant of the Fabaceae family that is used as an herb, mainly in the Mediterranean region, southern Europe, and western Asia. The Fabaceae or Leguminosae are flowering plants commonly known as the legume and pea or bean families. Allergic reactions to fenugreek are uncommon $[1,2]$. Patients sensitized to the peanut allergens Ara h 1 and Ara h 3 were reported to show cross-reactivity to $7 \mathrm{~S}$ vicilin-like and $11 \mathrm{~S}$ legumin-like allergens in fenugreek [3].
We report the case of a 34-year-old atopic woman who presented at our university allergy department 5 months ago with a history of facial flushing, angioedema, dyspnea, nausea, vomiting, and diarrhea shortly after ingestion of a Chinese vegetable soup (Ring and Messmer, grade III). On a second occasion, ingestion of a pork sausage with mixed spices led to a similar clinical picture. She also reported atopic dermatitis and known peanut allergy that had led to severe immediatetype reactions in childhood. Allergic rhinitis due to timothy grass was currently being treated with allergen-specific immunotherapy. She also had perennial asthma, which was being treated with inhaled corticosteroids and long-acting $\beta_{2}$-agonists.

The result of skin prick testing (ALK-Abelló) was positive for timothy grass, mugwort, and peanut. Prickto-prick testing with foods showed a wheal of $2 \mathrm{~mm}$ for pork sausage and was negative for pork and beef. Specific IgE (CAP FEIA, Thermo Fisher) was positive for Ara $\mathrm{h} 1$ (3.88 kU/L), Ara h $2(8.56 \mathrm{kU} / \mathrm{L})$, Ara h $3(0.36 \mathrm{kU} / \mathrm{L})$, Art v $3(0.75 \mathrm{kU} / \mathrm{L})$, and fenugreek seeds $(2.1 \mathrm{kU} / \mathrm{L})$ and negative for $\alpha$-gal, Tri a 19 , Tri a 14 , celery, pork, Bet v 1 , and Art v 1. Total $\operatorname{IgE}(57.2 \mathrm{kU} / \mathrm{L})$ and serum tryptase were within the normal range. A titrated, single-blind, placebocontrolled oral challenge test (OCT) was performed with celery (maximum single dose of $20 \mathrm{~g}$, cumulative dose of $40 \mathrm{~g}$ ), caraway (maximum single dose of $20 \mathrm{~g}$, cumulative dose of $40 \mathrm{~g}$ ), mugwort (maximum single dose of $20 \mathrm{~g}$, cumulative dose of $40 \mathrm{~g}$ ), and fenugreek (cumulative dose of $5 \mathrm{mg}$ ) on separate days. Celery and caraway were both ingredients in the ingested food, and a cross-reaction was suspected because of the patient's sensitization to mugwort. While caraway was well tolerated, celery and mugwort induced oral contact urticaria and allergic rhinitis. Five
A
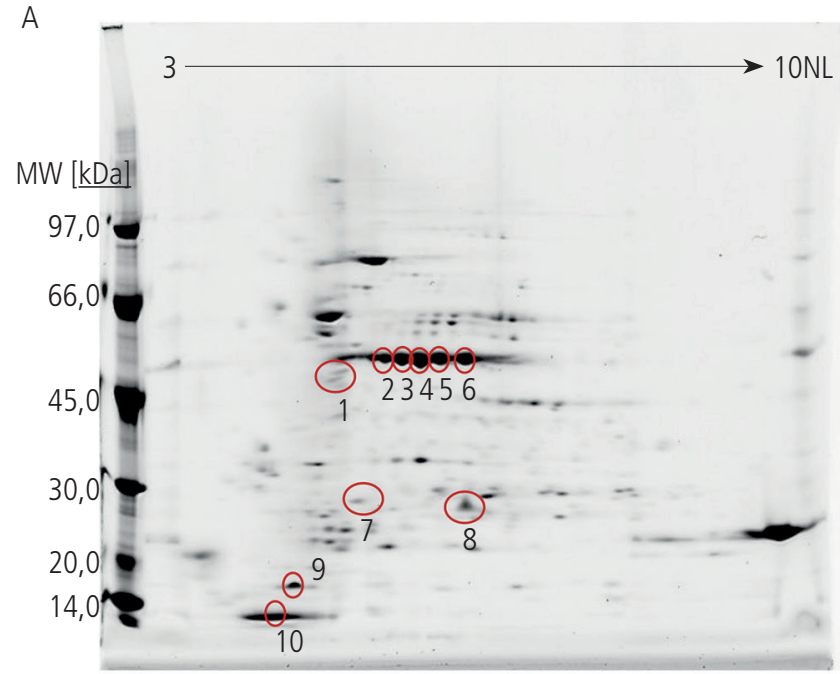

B

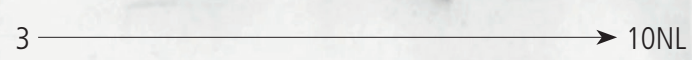

MW [kDa]

97,0

66,0

45,0

30,0

20,0

14,0

Figure. A, 2D-SDS-PAGE gel of fenugreek seed. Proteins identified by mass spectrometry: spot 1, vicilin (Pea, Pis s 1 [SC, 10.4\%]); spot 2-6, vicilin (Lentil, Len C 1 [SC, 17.9\%]; Pea, Pis S 1 [SC, 13.5\%]); spot 7, lectin (white clover, Acc. No. Q2LGCO [SC, 11\%]), 2 Uncharacterized proteins (wheat, Acc. No. W5C8S1 [SC, 3.8\%] and Acc. No. W5C930 [SC, 5.1\%]); spot 8, Uncharacterized protein (kidney bean, Acc. No. V7CBY4 [SC: 1.2\%]), predicted protein (moss, A9U500 [SC, 3.2\%]); spot 9, ABA-responsive protein (barrel clover, Acc. No. G7INB7 [SC, 12.7\%]) late embryogenesis abundant protein (barrel clover, Acc. No. G7ITI1 [SC, 9.7\%]); spot 10, no identification. B, 2D-Immunoblot of fenugreek seed. SC indicates protein sequence coverage. 
minutes after ingestion of fenugreek, the patient developed oral contact urticaria, abdominal pain, nausea, dyspnea, and generalized urticaria. The symptoms resolved completely with intramuscular epinephrine and intravenous prednisolone and dimethindene.

IgE-immunoblotting and mass spectrometry were used to identify and characterize potential fenugreek allergens. Fenugreek proteins were extracted from the fenugreek powder/seeds using Tris-ammonium pentaborate buffer ( $\mathrm{pH}$ 8.7), Tris-glycine buffer ( $\mathrm{pH} 8.7$ ), and ammonium carbonate buffer ( $\mathrm{pH} 7.9$ ) and pooled. Twenty micrograms of protein was separated using 2-dimensional electrophoresis. The first dimension was performed on a Protean IEF Cell (BioRad), and the second was performed on an Invitrogen XCell Sure Lock Mini Cell system (Whatman Protran BA83). Immunodetection was performed with the patient's serum (diluted 1:5 in PBS) and a horseradish peroxidaselabelled mouse monoclonal antibody targeting human IgE (Southern Biotechnology). SYPRO Ruby-stained protein spots were manually matched with IgE-reactive spots on the membrane, excised, and subjected to tryptic digestion and mass spectrometry, as published elsewhere [4]. They were then modified according to Spiric et al [5]. Protein Lynx Global Server version 3.03 (Waters) and the UniProt database (April 2014) restricted to entries for green plants were used for the data analysis after application of standard processing parameters.

In total, 8 proteins were identified in IgE-binding spots by mass spectrometry. These were matched with the protein sequences from other sources (Figure). A number of peptides with sequence identity to Len c 1 from lentil and Pis s 1 from peas were identified in spots 1-6, which belong to the vicilin protein family ( $<55 \%$ sequence identity to Ara $h 1)$. Additionally, the proteins in the most intense IgE spots on the gel were identified as lectin and uncharacterized proteins of wheat (spot 7) and of kidney beans and moss plants (spot 8). These proteins have not been reported to be allergenic in other plants, and no clinically relevant allergy was found to any of these allergens in the present case.

Additionally, the patient's serum showed IgE binding to major peanut allergens on 1D immunoblot for Ara h 1, Ara h 3, Ara h 2, and Ara h 6 (data not shown, although the peptide homologues were absent in the fenugreek extract).

Sequencing the fenugreek genome in combination with proteomic analysis of fenugreek extract would enable better identification of the culprit proteins responsible for the allergic reaction, since in most reported cases, fenugreek allergens from cross-reactions to peanut allergens were not identified, and cross-reactivity to other legumes such as soy and lupin has also been demonstrated [6-8]. Cross-reactivity to the lipid transfer protein of mugwort (Art v 3) and celery is also possible, although the clinical reaction to celery and mugwort in the challenge was clearly less intense than to fenugreek.

The low-molecular-weight range proteins in fenugreek extract appear to be more relevant in the present case owing to the fact that the IgE-binding reactivity observed was more pronounced than with the high-molecular-weight proteins.
Therefore, further studies on optimization of extraction would be beneficial for more precise identification of culprit proteins.

Unfortunately, the patient was lost to follow-up and not available for further investigations, such as cross-inhibition testing.

In summary, we present a rare case of anaphylactic reaction to fenugreek due to unknown allergens.

Fenugreek is used as an ingredient not only in mixed spices, but also in natural remedies, artificial maple syrup, coffee substitute, cheese, and supplement in baked goods [9]. In Europe, fenugreek does not have to be declared, thus making avoidance very difficult and challenging for patients whose primary allergy is to peanut [10].

\section{Funding}

The authors declare that no funding was received for the present study.

\section{Conflicts of Interest}

The authors declare that they have no conflicts of interest.

\section{References}

1. Faeste CK, Namork E, Lindvik H. Allergenicity and antigenicity of fenugreek (Trigonella foenum-graecum) proteins in foods. J Allergy Clin Immunol. 2009 Jan;123(1):187-94.

2. Che CT, Douglas L, Liem J. Case reports of peanut-fenugreek and cashew-sumac cross-reactivity. J Allergy Clin Immunol Pract. 2017 Mar - Apr;5(2):510-1.

3. Faeste CK, Christians U, Egaas E, Jonscher KR. Characterization of potential allergens in fenugreek (Trigonella foenumgraecum) using patient sera and MS-based proteomic analysis. J Proteomics. 2010 May 7;73(7):1321-33.

4. Shevchenko A, Wilm M, Vorm O, Mann M. Mass spectrometric sequencing of proteins silver-stained polyacrylamide gels. Anal Chem. 1996;68(5):S850-8.

5. Spiric J, Engin AM, Karas M, Reuter A. Quality Control of Biomedicinal Allergen Products - Highly Complex Isoallergen Composition Challenges Standard MS Database Search and Requires Manual Data Analyses. PloS One 2015;10(11):e0142404.

6. Dooper MM, Plassen C, Holden L, Lindvik H, Faeste CK. Immunoglobulin $\mathrm{E}$ cross-reactivity between lupine conglutins and peanut allergens in serum of lupine-allergic individuals. J Investig Allergol Clin Immunol. 2009;19:283-91.

7. Jensen LB, Pedersen MH, Skov PS, Poulsen LK, BindslevJensen C, Andersen SB, et al. Peanut cross-reacting allergens in seeds and sprouts of a range of legumes. Clin Exp Allergy. 2008;38:1969-77.

8. Vinje NE, Namork E, Løvik M. Cross-allergic reactions to legumes in lupin and fenugreek-sensitized mice. Scand J Immunol. 2012 Oct;76(4):387-97. 
9. Løvik M, Namork E, Fæste C, Egaas E. The Norwegian National Reporting System and Register of Severe Allergic Reactions to Food. Norwegian J Epidemiol. 2004;14:155-60.

10. Namork E, Fæste CK, Stensby BA, Egaas E, Løvik M. Severe allergic reactions to food in Norway: a ten year survey of cases reported to the food allergy register. Int J Environ Res Public Health. 2011 Aug;8(8):3144-55.

Manuscript received July 3, 2018; accepted for publication September 24, 2018.

Stefanie Aurich

Universitätsmedizin Leipzig

Klinik für Dermatologie, Venerologie und Allergologie

Ph.-Rosenthal-Str. 23

04103 Leipzig

E-mail: Stefanie.aurich@uniklinik-leipzig.de 